\section{NOVÝ PORTÁL PRO PREZENTACI MEZINÁRODNÍ KLASIFIKACE NEMOCÍ MKN-10}

\section{Matěj Karolyi, Petr Panoška, Martin Komenda, Linda Medková, Miroslav Zvolský}

\section{Anotace}

Ústav zdravotnických informací a statistiky České republiky (ÚZIS ČR) vytváří a udržuje nový portál pro prezentaci obsahu Mezinárodní klasifikace nemocí (MKN-10). Nový portál má být důležitým veřejně přístupným nástrojem pro snadnější prohližení struktury MKN-10, práci s ní a tzv. asistované kódování zdravotních služeb. Dostupnost takové služby je stěžejní pro správné vykazování činnosti poskytovatelů zdravotní péče zdravotním pojištovnám a do Národního zdravotnického informačního systému, a tedy i stabilitu celého českého zdravotnického systému. Portál nahrazuje dosavadní tištěnou i elektronickou distribuci klasifikace a vhodně doplní (i na základě další integrace) zjednodušené číselníky, nyní majoritně používané v klinických informačních systémech. Nástroj je aktivně vyvíjen a implementovaná funkcionalita reflektuje požadavky dlouhodobých primárních uživatelů i odborných testerů, kteří dostávají obsah i formu k oponentským řízením.

\section{Klíčová slova}

asistované kódování, fulltext vyhledávání, klasifikace onemocnění, mezinárodní klasifikace nemocí, software, webový portál, zdravotnictví

\section{Úvod}

Potřeba systematicky klasifikovat nemoci patří mezi dlouhodobé priority Světové zdravotnické organizace (WHO). Mezinárodní statistická klasifikace nemocí (International Classification of Diseases and Related Health Problems - ICD, MKN), za kterou právě Světová zdravotnická organizace stojí, kodifikuje systém klasifikace lidských onemocnění, poruch, př́znaků s nemocemi souvisejících či okolností a situací, které k onemocnění vedly. Je postavená na rozřazení pojmů do jednotlivých kategorií a každému pojmu je následně priirazen kód, který pak pojem reprezentuje a odpovídá zařazení v kategorii [1].

VČeské republice se aktuálně pracuje s jedenáctou revizí MKN (MKN-10) od roku 1994. Během následujících let prodělala řadu větších aktualizací v letech 2008, 2012 a 2017 a menších úprav a uzpůsobení v dalších letech. V České republice se tato verze běžně používá pro kódování príčin smrti na tzv.,Listu o prohlídce zemřelého". Také pak při vykazování zdravotní péče, vedení zdravotnické dokumentace a $v$ nemocničních informačních systémech [1], [2]. Ústav zdravotnických informací a statistiky České republiky nabízí mimo přehledový portál MKN-10 i nástroj obsahující Interaktivní výukový program této klasifikace.

\section{Původní portál MKN-10 pro ČR}

V době první větší aktualizace MKN-10 v roce 2008 vyvinul ÚZIS ČR podle mezinárodního a německého vzoru obsahu Tabelární části MKN-10 podobnou prezentaci pro české vydání této klasifikace (Obr. 1). Ta umožňuje interaktivní zobrazení struktury klasifikace s hypertextovými odkazy, které navigují uživatele strukturou kapitol, oddílů, trímístných a čtyřmístných kódů. Webová prezentace byla tvořena exportem podkladových dat do struktury HTML souborů (po jednotlivých oddílech) společně s vygenerováním souboru se skripty jazyku Javascript pro navigační menu (v pravé části okna prohlížeče).

Technické řešení má několik zásadních omezení.

- Při každé aktualizaci obsahu klasifikace je třeba provést jednorázové přegenerování HTML souborů.

- Odkazování obsahu je možné pouze na konkrétní oddíl, jehož samostatné zobrazení pak neumožňuje navigaci zbytkem Tabelární části (HTML rámy).

- Fulltextové vyhledávání je řešeno externě přes služby Google.

\section{Technické aspekty}

Nový webový portál MKN-10 zobrazuje strukturu využívané klasifikace lidských onemocnění. Uživatelé s portálem komunikují prostřednictvím prohlížeče. Komunikace mezi klientem a serverem je zašifrována pomocí protokolu SSL. Architektura celého portálu je modulární s využitím moderních nástrojů a knihoven.

\subsection{Architektura portálu}

Aplikační architektura se dá rozdělit na několik modulů. V první radě je to databáze vystavěná v open-source databázovém systému PostgreSQL $10^{2}$, která obsahuje zdrojová data klasifikač-

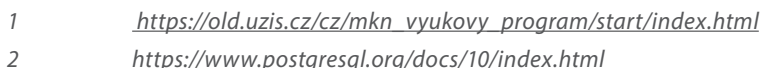

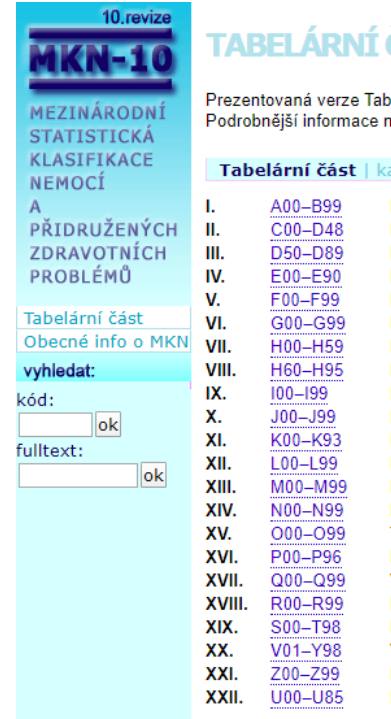

Prezentovaná verze Tabelárni části MKN-10 vstoupila v platnost 1. 1. 2020 sdělením Českého statistického úradu. c ćlánku $k$ MKN jako celk

tola: A00-B99

Nẽkteré infekčni a parazitárni nemoci

Novotvary

Nemoci krve, krvetvornyych orgánú a nẽkteré poruchy týkajicí se mechanismu imunity Nemoci endokrinni, vy̌živy a přeměny látek

Poruchy duševni a poruchy chovani

Nemoci nervove soustavy

Nemoci ucha a bradavkového výběžku

Nemoci obèhove soustavy

Nemoci dýchaci soustavy

Nemoci trávicí soustavy

Nemoci kúže a podkožniho vaziva

Nemoci svalove a kosterni soustavy a pojivové tkánè

Nemoci močové a pohlavni soustavy

Tĕhotenství, porod a šestinedĕli

Nẽkteré stavy vzniklé v perinatálním obdobi

Vrozené vady, deformace a chromozomální abnormality

Príznaky, znaky a abnormální klinické a laboratorní nálezy nezařazené jinde

Poranění, otravy a některé jiné následky vnějšich príǐ̌in

Vnějši prííiny nemocnosti a úmrtnosti

Faktory ovlivňujicí zdravotni stav a kontakt se zdravotnickými službami

Kódy pro speciálni účely

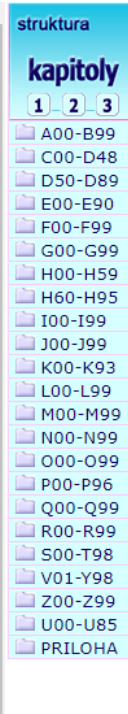

Obrázek 1- Webová prezentace tabelární části MKN-10 z roku 2008 


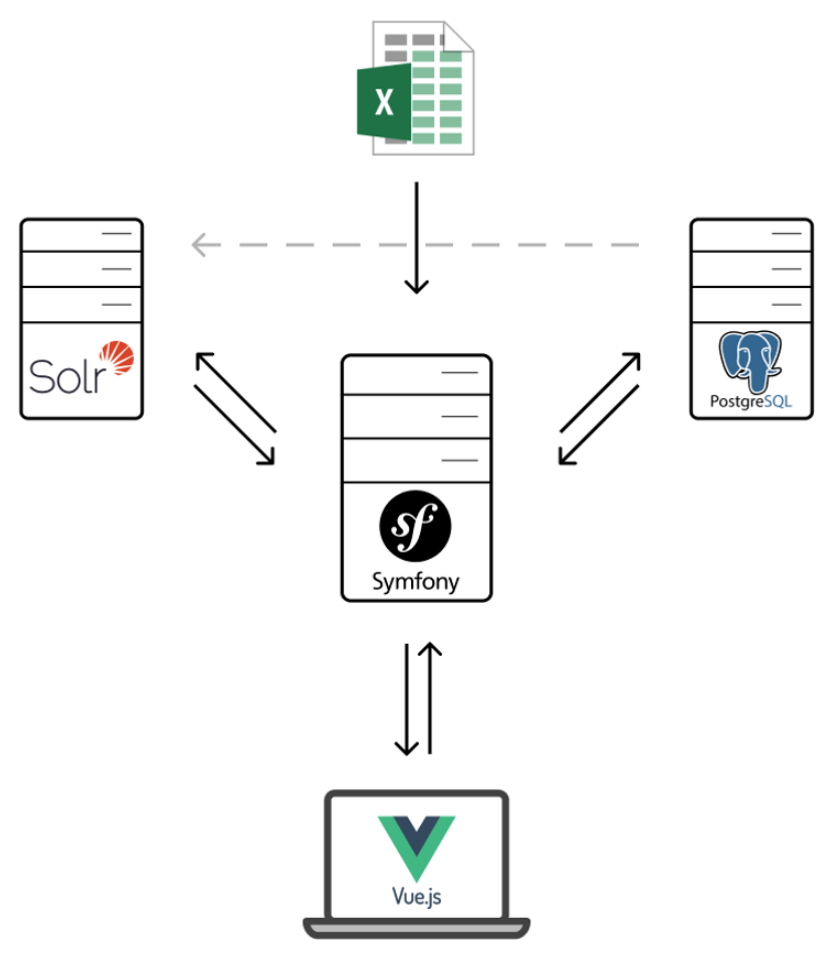

Obrázek 2 - Schéma architektury aplikace a datového toku

ního systému. Dalším modulem je indexovací nástroj Apache Solr ve verzi 7.7.1 [3], který zajištuje fulltextové vyhledávání $v$ datech klasifikace. Hlavním modulem je jádro aplikace, které je implementováno $v$ jazyce PHP, za použití moderního a v praxi hojně využívaného PHP frameworku Symfony 5 [4]. Ten zajištuje komunikaci s ostatními moduly aplikace, a nakonec samotný běh webové aplikace. Během návrhů vývoje a implementace tento framework významně urychluje jednotlivé fáze. Současně usnadňuje jeho rozšiřitelnost a zabezpečuje dlouhodobou udržitelnost. Pro implementaci uživatelského rozhraní webové aplikace byl využit framework Vue.js ${ }^{3}$.

\subsection{Datový tok}

Zdrojová data představují tabelární a abecední seznamy, které

$3 \quad$ https://vuejs.org/ jsou doprovázeny seznamy pravidel a příkladů kódování. Primární data jsou uložena $v$ souboru XLSX a mají jednoznačně definovanou strukturu, kterou Ize strojově zpracovávat. Tento primární datový soubor je dále zpracován jádrem aplikace, přičemž dochází k importu dat do databáze PostgreSQL. Komunikaci jádra s databází umožňuje ORM framework Doctrine. Po importu následuje napojení nástroje Apache Solr na databázi a vytvoření indexu pro fulltextové vyhledávání. Pro jednodušší dotazování na index jádrem aplikace byla použita PHP knihovna Solarium ${ }^{4}$. Schéma datového toku a aplikační architektura jsou znázorňuje Obr. 2.

\subsection{Podpora prohlížečů}

Webová aplikace je optimalizovaná pro většinu nejpoužívanějších prohlížečů, tedy Google Chrome, Mozilla Firefox, Microsoft Edge a Internet Explorer. Na mobilních zařízeních je aplikace dostupná v omezeném zobrazení, které bude rozšíreno po fázi uživatelského testování a následného připomínkového řízení.

\section{Komponenty portálu}

Celý portál MKN-10 obsahuje několik uživatelských funkcionalit. Několik z nich vychází z dřive používaného portálu MKN-10, který je spravován ÚZIS ČR. Další podněty pro vývoj byly převzaty z nástroje vydaného Světovou zdravotnickou organizací, které byly doplněny o další specifikaci. Komponenty jsou dále upravovány dle připomínek odborných uživatelů. Portál je přístupný na adrese https://mkn10.uzis.cz/.

\subsection{Prohlížeč struktury klasifikačního systému}

Základem webové aplikace je zobrazení hierarchické struktury klasifikace, definic jednotlivých položek, ale také zobrazení dalšího kontextového obsahu. Jedná se především o pravidla pro kódování diagnóz v různých prostředích (úmrtnost, hospitalizační péče), klinických př́kladů pro použití jednotlivých kódů v systému vykazování zdravotní péče nebo i externího obsahu (např. Wikiskripta) indexovaného pomocí kódů MKN-10. Zobrazená klasifikace je propojena prostřednictvím odkazů na související kódy.

Obr. 3 obsahuje pohled na prohlížeč struktury klasifikace. $\checkmark$ levém bočním panelu je viditelný úplný strom klasifikace v podobě víceúrovňového seznamu, který je složený z rozbalo-

$4 \quad$ https://github.com/solariumphp/solarium

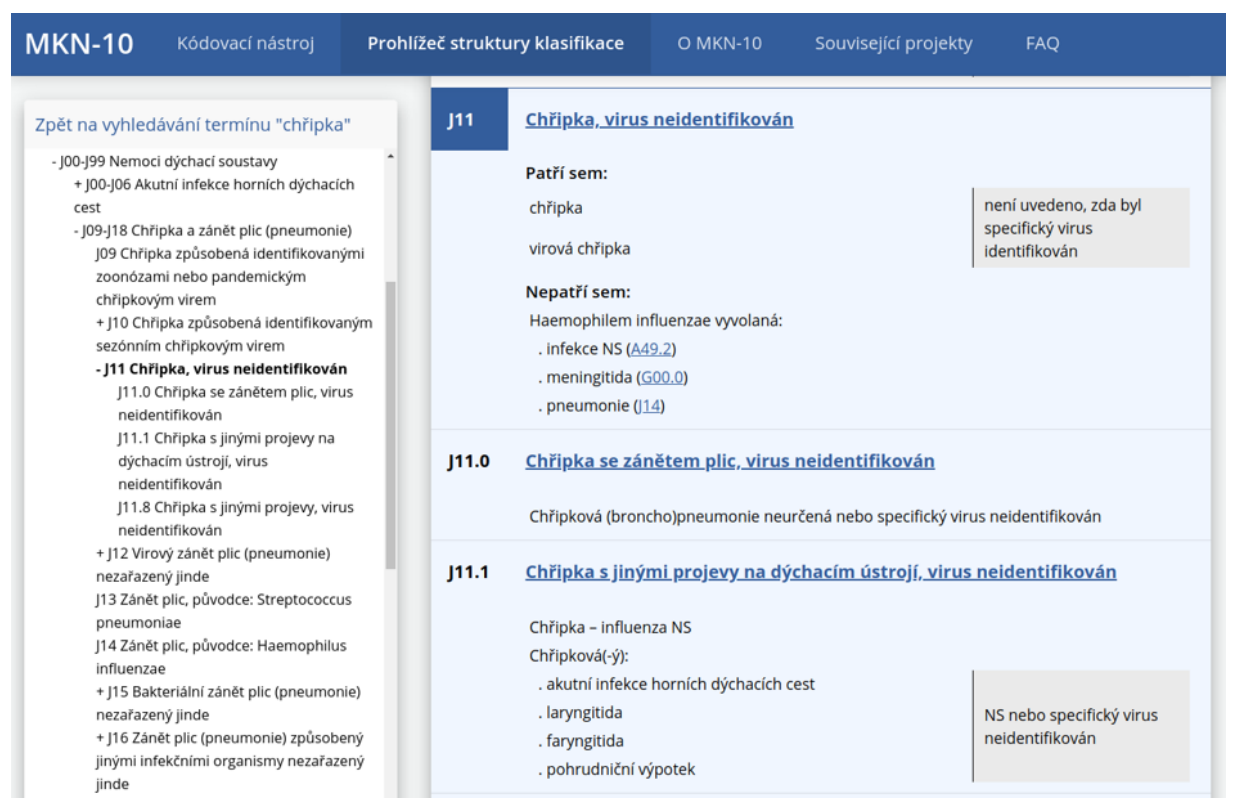

Obrázek 3 - Prohližeč struktury klasifikačního systému 


\section{J09-J18 - Chřipka a zánět plic (pneumonie)}

Nadřazená kapitola: J00-J99 - Nemoci dýchací soustavy.

J09

Chr̆ipka způsobená identifikovanými zoonózami nebo pandemickým chřipkovým virem

Chřipka vyvolaná vyjmenovanými chřipkovými virovými kmeny zvláštní epidemiologické důležitosti s přenosem ze zviřete na člověka nebo z člověka na člověka.

K vyznačení pneumonie nebo jiných projevů použijte dodatkový kód.

Nepatří sem:

Haemophilem influenzae vyvolaná:

. infekce NS (A49.2)

. meningitida (G00.0)

. pneumonie $(1414)$

chřipka způsobená identifikovaným sezónním chřipkovým virem J10.-)

Poznámka:

Pro použití této položky je potřeba se odkázat na instrukce WHO k celosvětovému programu chřipky (GIP, http://www.who.int/influenza).

Patří sem:

chřipka způsobená identifikovaným virem chřipky typu B nebo C

Nepatří sem:

Haemophilem influenzae vyvolaná:

Obrázek 4 - Detail kapitoly J09-J18

\begin{tabular}{|c|c|}
\hline A00.1 & $\begin{array}{l}\text { Cholera, původce: Vibrio cholerae 01, biotyp el Tor } \\
\text { Cholera eltor [Cholera el Tor] }\end{array}$ \\
\hline A00.9 & Cholera NS \\
\hline A01 & Briššni tyfus a paratyfus \\
\hline A01.0 & $\begin{array}{l}\text { Brĭišni tyfus } \\
\text { Infekce, püvodce: Salmonela typhi }\end{array}$ \\
\hline A01.1 & Paratyfus $\mathrm{A}$ \\
\hline A01.2 & Paratyfus B \\
\hline A01.3 & Paratyfus C \\
\hline A01.4 & $\begin{array}{l}\text { Paratyfus NS } \\
\text { Infekce, püvodce: Salmonela paratyphi }\end{array}$ \\
\hline A02 & Jiné infekce způsobené salmonelami \\
\hline & Patř̆ sem: \\
\hline
\end{tabular}

Obrázek 5 - Pravidlo k položce A00.1

vacích kapitol, podkapitol a také všech kódovaných položek. Na základě výběru konkrétní položky seznamu se do hlavní části prohlížeče vygeneruje detail k prohlížení.

\subsection{Detaily kapitol a kódovaných položek}

Portál poskytuje podrobné výpisy kapitol i kódovaných položek. Ty jsou částečně interaktivní a propojené s dalšími detaily. Uživatel tak může traverzovat mezi souvisejícími pojmy - tzv. přidruženými položkami. Ty se dělí do dvou hlavních skupin:

- Patří sem - související kódované položky

- Nepatří sem - explicitně nesouvisející kódované položky

Na Obr. 4 je viditelný detail podkapitoly J09-J18 - Chřipka a zánět plic (pneumonie). Ten obsahuje odkaz na svou nadřazenou kapitolu, základní informace a přidružené položky. Tento detail je stále viditelně ukotven ve struktuře celé klasifikace MKN-10.
Každý takový detail je možné odkazovat prostřednictvím jasně definovaného unikátního odkazu. $V$ tomto prípadě https:// mkn10.uzis.cz/prohlizec/J09-J18. Strojové generování takovýchto odkazů je velice jednoduché a umožní tedy externím aplikacím a portálům jednoduše simulovat strukturu prohlížeče a využívat jej jako doplnění informací ke kódům kapitol i položek.

\subsection{Klasifikační pravidla a př́klady}

$\checkmark$ některých prípadech jsou kódované položky doplněny o klasifikační pravidla nebo príklady klasifikace. Tyto dodatečné informace jsou dostupné v rozšiřujícím sloupci detailu položky samotného prohlížeče struktury klasifikace. Pomáhají upřesnit a vysvětlit povahu kódovaných položek. Obr. 5 ukazuje pravidla pro položku A01: Břišní tyfus a paratyfus ${ }^{5}$. Je zde prístupný odkaz na metodiku kódování diagnóz i možnost filtrovat pravidla

$5 \quad$ https://mkn10.uzis.cz/prohlizec/A01 


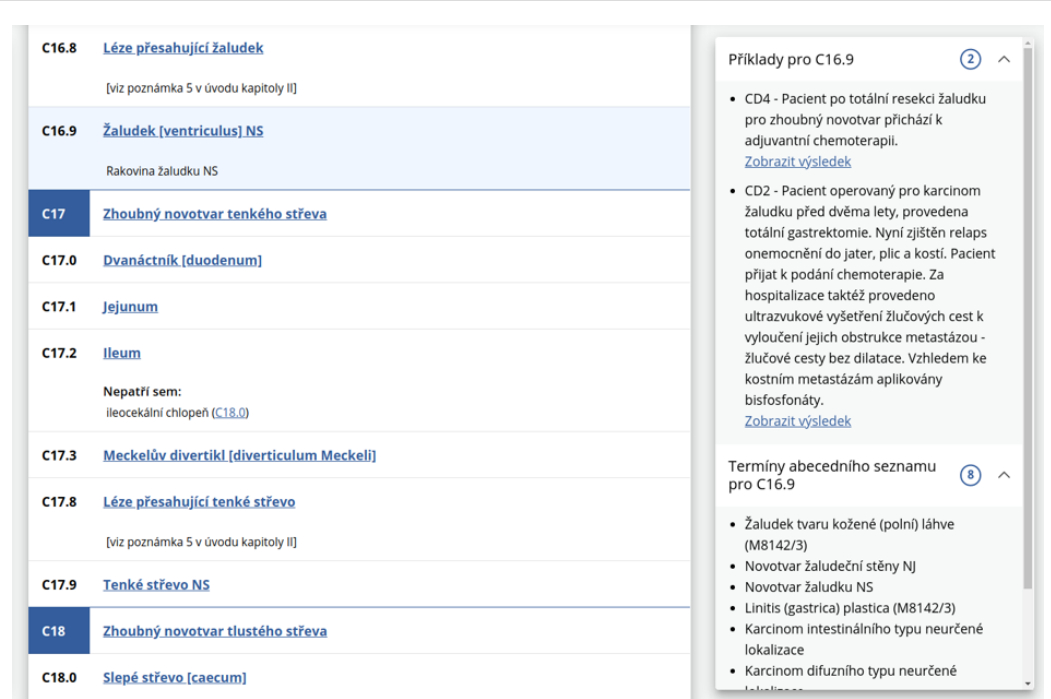

Obrázek 6 - Př́klady pro diagnózu C16.9

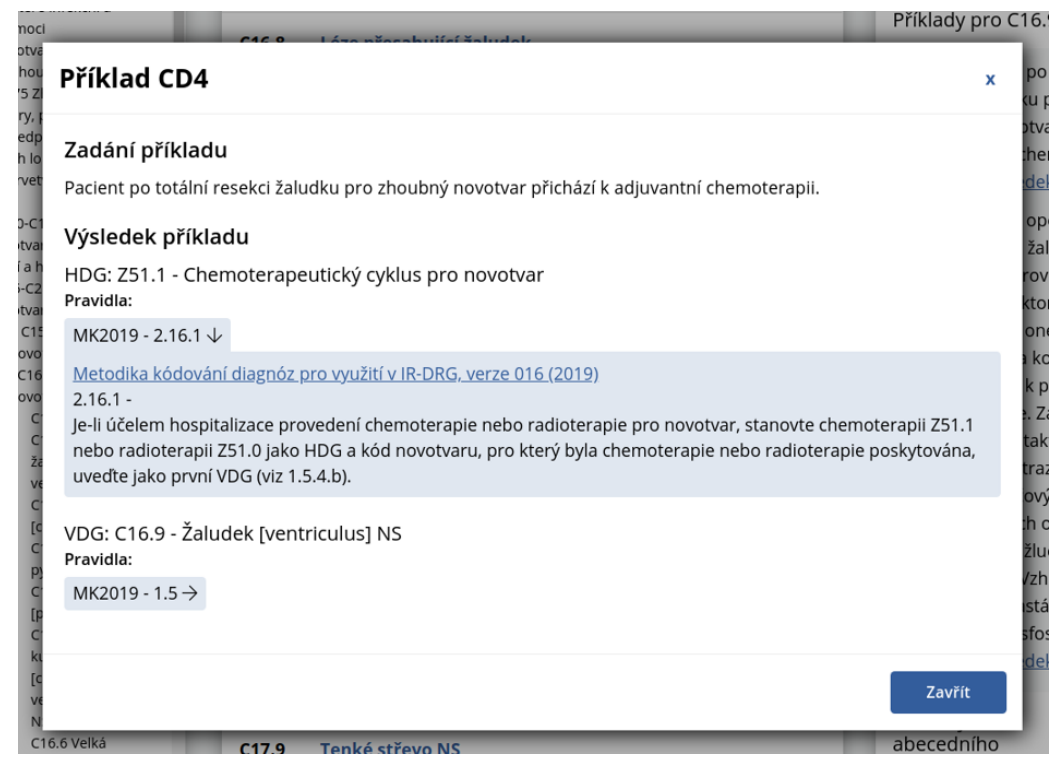

Obrázek 7 - Detail príkladu CD4

dle jejich platnosti. Zpřístupněny jsou i termíny abecedního seznamu s indikací jejich počtu - A01.3: Paratyfus C. ${ }^{6}$ Konečně príklady jsou zobrazovány podobným způsobem hned pod pravidly.

Příklady představují modelové situace z klinického prostředí a jejich výsledkem je ukázka správného kódování pomocí jednotlivých diagnóz. Výsledek příkladu je vždy právě jedna hlavní diagnóza, popř́padě několik dalších vedlejších diagnóz. U výsledného kódování diagnózy je také uvedeno jedno nebo více pravidel. Obr. 6 zachycuje př́klady u jejichž výsledků vystupuje diagnóza C16.9 - Žaludek [ventriculus] NS7. Na Obr. 7 je zobrazen detail výsledku př́kladu CD4.

\subsection{Kódovací nástroj}

Důležitou součástí portálu je „Kódovací nástroj“, obdoba tzv. Coding tool vyvíjeného Světovou zdravotnickou organizací (WHO) v mezinárodní verzi MKN-10. Ten umožňuje fulltextové vyhledání vhodného kódu MKN-10 pro zadaný termín klinického stavu nebo jeho fragment. Vyhledávání je realizováno jak v Tabelární části MKN-10, tak Abecedním seznamu, tedy terminologickém rejstř́ku klasifikace.

$\begin{array}{ll}6 & \text { https://mkn10.uzis.cz/prohlizec/A01.3 } \\ 7 & \text { https://mkn10.uzis.cz/prohlizec/C16.9 }\end{array}$

Výsledky jsou razeny dle relevance nebo dle uspořádání ve struktuře klasifikace. Je ponecháno na uživateli, jakým způsobem chce výsledky seřadit. Nalezené položky jsou označeny podle toho, v které části klasifikace byl termín nalezen a v jakém kontextu.

Kontext vyhledávaného termínu je zachován i při následném nahlížení do struktury klasifikace. Uživatel se tedy může vždy vrátit zpět k hledanému pojmu. Každé provedené vyhledávání je identifikováno specifickým odkazem a je tedy možné si jej uložit, prípadně sdílet. Na Obr. 8 je znázorněn výsledek vyhledávání pro frázi "chřipka". Tento dotaz je možné znovu opakovat pomocí uloženého odkazu ${ }^{8}$.

\section{Shrnutí a navazující aktivity}

Prezentovaný webový portál, spravovaný ÚZIS ČR, má sloužit svým uživatelům k zobrazení struktury klasifikačního systému MKN-10. Po řádném připomínkovém řízení a reflektování požadavků profesionálních kodérů je ambicí tento nástroj používat jako náhradu stávající prezentace z roku 2008. Oproti té je nový portál lépe udržitelný a nabízí širší paletu funkcionality, zejmé-

8 https://mkn10.uzis.cz/?term=chřipka\&limit=10\&page=1 


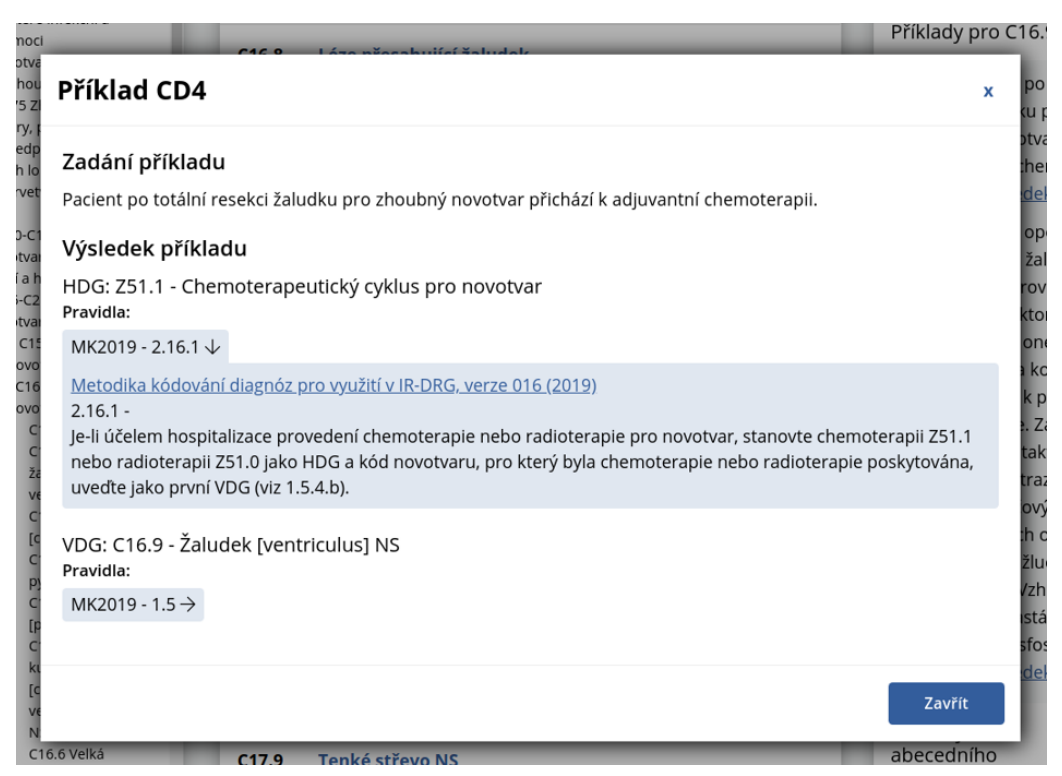

Obrázek 8 - Vstupní rozhraní kódovacího nástroje s vyhledaným pojmem "chřipka"

na pak kódovací nástroj s podporou fulltextového vyhledávání v abecedním a tabulárním seznamu kódovaných položek.

Významnou částí celého nástroje by $v$ budoucnu mělo být volně dostupné aplikační rozhraní (Application Programming Interface - API), které bude klasifikaci vystavovat ve strojově zpracovatelné formě. Toto rozhraní by pak mohly využívat aplikace a služby třetích stran k různým účelům.

Již nyní je plánováno portál https://mkn10.uzis.cz/ a jeho detaily kódovaných položek a kapitol odkazovat v dalších portálech ÚZIS ČR tak, aby doplnily celkový kontext zobrazovaných informací.

\section{Literatura}

[1.] M. Reimer, A. Schlenker, M. Komenda, and M. Zvolský, "NOVÝ WEBOVÝ PORTÁL A WEBOVÉ SLUŽBY PRO PREZENTACI MEZINÁRODNÍ KLASIFIKACE NEMOCI (MKN)," MEDSOFT 2018, p. 3.

[2.] "Mezinárodní klasifikace nemocí MKN - ÚZIS ČR." [Online]. Available: https://www.uzis.cz/index.php?pg=registry-sber-dat--klasifikace--mezinarodni-klasifikace-nemoci. [Accessed: 16-Feb-2020].

[3.] "Mastering Apache Solr 7.x." [Online]. Available: https://www.packtpub.com/big-data-and-business-intelligence/mastering-apache-soIr-7x. [Accessed: 16-Feb-2020].

[4.] F. Potencier, Symfony 5: The Fast Track. Symfony SAS, 2019.

\section{Kontakt}

Matěj Karolyi

e-mail:matej.karolyi@uzis.cz

Petr Panoška

e-mail:petr.panoska@uzis.cz

Martin Komenda

e-mail: martin.komenda@uzis.cz

Linda Medková

e-mail: linda.medkova@uzis.cz

Miroslav Zvolský

e-mail: miroslav.zvolsky@uzis.cz

Ústav zdravotnických informací a statistiky České republiky web: https://uzis.cz/ 